\title{
Partial Pancreatectomy in the Rat and Subsequent Defect in Glucose-induced Insulin Release
}

\author{
S. Bonner-Weir, D. F. Trent, and G. C. Weir, Endocrine Division, Department \\ of Medicine, Medical College of Virginia-Virginia Commonwealth \\ University, Richmond, Virginia 23298
}

\begin{abstract}
A B S T R A C T To define the consequences of a known reduction of $B$ cell mass in rats, $90 \%$ partial pancreatectomies were performed. For the 6 wk following surgery moderate hyperglycemia was maintained in the fed state but there were no differences in body weight nor plasma insulin concentrations compared with sham-pancreatectomized controls. 8-10 wk following surgery regeneration of the remnant was evident with remnant weight being $26 \%$, B cell mass being $42 \%$, and non-B cell mass being $47 \%$ of values found for control whole pancreas. There were comparable increases in the remnant content of insulin, glucagon, and somatostatin. Following meal challenges, intraperitoneal and intravenous glucose tolerance tests and intravenous arginine challenge given 6-7 wk after surgery, the insulin responses to glucose were blunted or absent but the responses following the meals or arginine were intact. Similarly, when the pancreatic remnant was perfused in vitro, insulin release after challenge with $300 \mathrm{mg} / \mathrm{dl}$ glucose was markedly reduced whereas intact responsiveness to $10 \mathrm{mM}$ arginine was retained. These data suggest that the chronic stimulation of a reduced $B$ cell mass can lead to a selective loss of glucose-induced insulin secretion.
\end{abstract}

\section{INTRODUCTION}

Noninsulin-dependent diabetes mellitus (NIDDM) ${ }^{1}$ in man is characterized by a defect in glucose-stimulated

A preliminary report of this work was presented at the 42nd Annual Meeting of the American Diabetes Association, June 1982, San Francisco.

Dr. G. C. Weir was the recipient of Research Career Development Award AM-00255 from the National Institutes of Health.

Received for publication 11 January 1983.

${ }_{1}$ Abbreviations used in this paper: IV ARG, intravenous arginine; IVGTT, intravenous glucose tolerance test; IPGTT, intraperitoneal glucose tolerance test; NIDDM, noninsulindependent diabetes mellitus. insulin release and retained sensitivity to such secretagogues as arginine, isoproterenol, and secretin (1-3). Recently we described a rat model produced by a neonatal injection of the B cell toxin streptozotocin, which was found to have a similar abnormality of insulin secretion $(4,5)$. It was hypothesized that this lesion may have resulted from chronic stimulation of a reduced B cell mass or from a long-term effect of streptozotocin. To explore the consequences of a reduction of B cell mass exclusive of the effects of streptozotocin, the classic model of partial pancreatectomy (6-10) was studied using the newer methods of radioimmunoassay (RIA), organ perfusion, immunochemistry, and quantitative morphometry.

\section{METHODS}

Partial pancreatectomy. 4-5-wk-old male Sprague-Dawley rats (95-125 g) were anesthetized with sodium amytal and $85-90 \%$ of their pancreas was removed by the technique of Folgia (8). The remnant (residual pancreas) was anatomically well defined, being the tissue within $2 \mathrm{~mm}$ of the common bile duct and extending from the duct to the first part of the duodenum. This remnant is the upper portion of the head of the pancreas thought to be embryologically of dorsal anlagen origin. Control animals were laparotomized and received a sham pancreatectomy that consisted of disengaging the pancreas from the mesentery and gently rubbing it between the fingers. Following surgery the animals were allowed to feed ad lib. on standard laboratory chow.

For the first week postoperatively body weight and plasma glucose values were followed daily. Then these values as well as the plasma insulin concentrations were followed at weekly intervals for $6 \mathrm{wk}$. Blood was collected in a heparinized glass tube by snipping the tail of a fed restrained rat and then centrifuged. For glucose measurements, $10 \mu$ l plasma was withdrawn, diluted with saline, and assayed using a Beckman Glucose Analyzer II (Beckman Instruments, Inc., Fullerton, CA). Pending assay for insulin, the plasma was frozen at $-20^{\circ} \mathrm{C}$.

Tissue extraction. $8-10 \mathrm{wk}$ following surgery, pancreases were dissected from decapitated rats, cleared of gut and major lymph nodes, rinsed in saline, blotted, weighed, and kept on ice until homogenization. Pancreases from sham 
animals were divided into the remnant equivalent (that portion of the pancreas with the same anatomical boundaries as the remnant left in the partial pancreatectomized animals as described above) and the rest. Data are presented for the remnant equivalent and the whole pancreas, which is the sum of the two portions. The tissue was homogenized in cold acid ethanol using an Ultra-Turrax SDT homogenizer (Tekmar Co., Cincinnati, $O H$ ). The samples were heated for 5 min in a $70^{\circ} \mathrm{C}$ water bath and then were adjusted in volume to $7 \mathrm{ml}$ for the major pancreatic portion of sham animals and $3 \mathrm{ml}$ for either the pancreatectomy remnant or the remnant equivalent and were stored at $-20^{\circ} \mathrm{C}$ until assayed.

Quantitative morphometry. Pancreases after perfusion (see below) were dissected, cleared of lymph nodes, fixed in Bouin's fixative, and embedded in paraffin. Adjacent sections of blocks of either remnant or remnant equivalent were stained by immunoperoxidase $(4,11)$ for either $B$ cells using guinea pig anti-porcine insulin antibody (the gift of Dr. Peter Wright, Indiana University Medical School, lot 607/27) or for the non-B cells using a slurry of rabbit antisynthetic somatostatin (our D-10), rabbit anti-bovine pancreatic polypeptide (the gift of Dr. R. Chance, Eli Lilly \& Co., Indianapolis, IN) and rabbit anti-porcine glucagon (the gift of Dr. M. Appel, University of Massachusetts Medical School). Control incubations using excess antigen added to immune sera, nonimmune sera as primary antibody, and omission of the primary antibody resulted in the absence of hormone-specific staining. The relative volumes of $B$ and non-B cells were quantitated by the point counting method of Weibel (12). At a magnification of $\times 400$ starting at a random point at one corner of the section, every other field was scored using a 25-point ocular grid. An unbiased but systematic selection of fields was easily accomplished using the markings of the stage micrometer. Intercepts over blood vessels, fat, ducts, lymph nodes, or interlobular space were subtracted to give the total pancreatic counts. The mean total counts for the pancreatectomized animals (mean $=7,263 \pm 640, n=7$ ) reflected the 1.7-fold greater amount of tissue than in the remnant equivalent (mean $=4,686 \pm 673, n=4$ ).

In vivo challenges. $6 \mathrm{wk}$ after pancreatectomy, animals were given different in vivo challenges. Some were given a meal challenge followed $6 \mathrm{~d}$ later by an intraperitoneal glucose tolerance test (IPGTT); others had an IPGTT followed $4 \mathrm{~d}$ later by an intravenous glucose tolerance test (IVGTT) and $4 \mathrm{~d}$ later by an intravenous arginine (IV ARG) challenge. For the meal challenge, animals were fasted $19 \mathrm{~h}$, bled at 0 time, given food, and then bled at 30 and $60 \mathrm{~min}$. All animals began eating within $10 \mathrm{~min}$ of receiving food. For the IPGTT, fasted (19 h) animals were bled at 0 time, injected intraperitoneally with enough $20 \%$ glucose solution to give a glucose load of $2 \mathrm{~g} / \mathrm{kg}$ body wt and then bled at 10,30 , and 50 min. 2-3 d before the intravenous challenges $(13,14)$ indwelling jugular catheters were put in place. Animals were fed but food was removed $1 \mathrm{~h}$ before the intravenous challenges. For the IVGTT, enough $60 \%$ glucose solution to give $1 \mathrm{~g} / \mathrm{kg}$ was injected into the cannula, which was then flushed with $1 \mathrm{ml}$ of heparinized saline. Samples were taken at $0,2,5,10$, and $30 \mathrm{~min}$. The same animals 4 $\mathrm{d}$ later were given in the same manner enough arginine hydrochloride solution $(180 \mathrm{mg} / \mathrm{ml}, \mathrm{pH} \mathrm{7.4)}$ to give a dose of $300 \mathrm{mg} / \mathrm{kg}$ arginine and samples were taken at $0,2,5$, and $15 \mathrm{~min}$.

In vitro challenge: pancreas perfusion. Insulin secretion was studied in three groups of fed rats 8-11 wk following surgery using the in situ isolated perfused pancreas technique (15), with the same surgical approach used in each. Two of the groups included rats that had received either pancreatectomies or sham pancreatectomies, as has been described herein. The third group included rats of the same body weight in which perfusate flow to the pancreas was acutely restricted to the remnant area defined above. This restriction was accomplished with additional surgical ties and verified by blanching of the area once the perfusion was initiated. In all perfusions there was a 20 -min equilibration period that followed the end of surgery and during this period the perfusate glucose concentration was $120 \mathrm{mg} / \mathrm{dl}$. The flow rate for rats with pancreatectomies averaged $2.2 \mathrm{ml} /$ min, for rats with sham operations was $2.7 \mathrm{ml} / \mathrm{min}$, and for the group with acute restrictive surgery was $2.0 \mathrm{ml} / \mathrm{min}$. Each group received the same protocol, which consisted of a base-line perfusate glucose concentration of $120 \mathrm{mg} / \mathrm{dl}$ and then 10-min challenges with first glucose at a concentration of $300 \mathrm{mg} / \mathrm{dl}$, which was infused via a side-arm syringe, and then arginine $(10 \mathrm{mM})$, delivered from a second reservoir. The exact timing of these perfusions is depicted in Fig. 3. Each sample was collected over a 60-s time period and Fig. 3 indicates the only samples that were obtained. Total insulin output over a given period of time was calculated by multiplying concentration of hormone in the perfusate by flow rate. In those time periods in which no sample was taken, values were calculated by extrapolation.

RIA. Insulin in the perfusate and extracts was measured by RIA using charcoal separation (16), with rat insulin (Novo Research Institute, Copenhagen, Denmark) used for standards. Glucagon was measured by RIA (15) using porcine glucagon as standard and antiserum $30 \mathrm{~K}$, the latter purchased from Dr. Roger H. Unger, University of Texas, Southwestern Medical School. Somatostatin was measured by a modification (17) of the method of Patel and Reichlin (18) using our antiserum D-6. Plasma insulin was measured with a double-antibody RIA (19).

Statistics. Results are presented as mean \pm standard error of the mean. Two-tailed unpaired Student's $t$ test was used throughout this study.

\section{RESULTS}

Quantification of the extent of pancreatectomy. The remnant of the pancreas was anatomically defined as described above. At the time of pancreatectomy (4-5 wk of age) the remnant was $12.1 \pm 0.5 \%$ of the total pancreatic weight and contained $9.7 \pm 1.0 \%$ of the total insulin content ( $n=6$, data not shown). 8-10 wk after surgery (12-14 wk of age) the same portion of the sham-pancreatectomized controls, called the remnant equivalent, was $10.5 \pm 1.0 \%$ of the total pancreatic weight and had $10.3 \pm 0.9 \%$ of the total pancreatic insulin content ( $n=6$; Table I).

Longitudinal study after partial pancreatectomy. Animals bled daily for the first week after pancreatectomy showed significant increases in the fed plasma glucose concentrations by day 4 (Fig. 1). This moderate hyperglycemia was maintained for the following 6 wk as shown in Fig. 2. During this time period there were no significant differences in body weight nor in plasma insulin concentration. Although a fed plasma glucose $>200 \mathrm{mg} / \mathrm{dl}$ was occasionally found for any animal at any weekly bleed, only one animal (of 23) so followed had values consistently this high; data from this animal was not included in the results.

Hormone content and tissue weight. The hormone 
TABLE I

Hormone Content of Remnant from Partially Pancreatectomized (Px) Rats, and of Remnant Equivalent and of Whole Pancreas from Sham-pancreatectomized (Sham Px) Rats ${ }^{\circ}$

\begin{tabular}{|c|c|c|c|c|c|c|c|}
\hline \multirow[b]{2}{*}{ Animals $(n)$} & \multirow[b]{2}{*}{ Tissue weight } & \multicolumn{2}{|c|}{ Insulin } & \multicolumn{2}{|c|}{ Glucagon } & \multicolumn{2}{|c|}{ Somatostatin } \\
\hline & & Content & Concentration & Content & Concentration & Content & Concentration \\
\hline & $g$ & $\mu g$ & $\mu g / g$ & $\mu g$ & $\mu g / g$ & $\mu g$ & $\mu g / g$ \\
\hline Px remnant $(8)$ & $0.303 \pm 0.036$ & $20.7 \pm 2.6$ & $71.44 \pm 7.85$ & $1.77 \pm 0.14$ & $6.09 \pm 0.47$ & $0.175 \pm 0.015$ & $0.620 \pm 0.060$ \\
\hline \multicolumn{8}{|l|}{ Sham Px (6) } \\
\hline Remnant equivalent & $0.125 \pm 0.012$ & $6.40 \pm 1.30$ & $54.4 \pm 12.8$ & $0.416 \pm 0.047$ & $3.37 \pm 0.34 \rrbracket$ & $0.091 \pm 0.013$ & $0.740 \pm 0.110$ \\
\hline Whole pancreas & $1.190 \pm 0.070$ & $64.0 \pm 11.7$ & $54.6 \pm 9.6$ & $5.83 \pm 0.62$ & $5.02 \pm 0.65$ & $0.824 \pm 0.054$ & $0.700 \pm 0.050$ \\
\hline
\end{tabular}

- Pancreatic specimens were excised 8-10 wk after surgery (12-14 wk of age). The remnant equivalent is that portion of the pancreas contained roughly within the anatomical boundaries of the bile duct and duodenum as defined in Methods.

$\downarrow$ Differs from $P x$ remnant $(2 P \leq 0.001)$ and from whole pancreas $(2 P \leq 0.05)$.

content and concentrations of insulin, glucagon, and somatostatin for the pancreatectomy remnant, the remnant equivalent, and the whole sham pancreatectomized pancreas 8-10 wk following surgery are presented in Table I. At this time the remnant equivalent was still $\sim 10 \%$ of the pancreatic weight and had $10 \%$ of the content of insulin and somatostatin. However, the remnant of the pancreatectomized animals showed increased growth and was $26 \%$ of the total pancreatic weight with $32 \%$ of the total insulin content. It is of interest that with the enhanced growth of the pancreatectomy remnant the hormone concentration of all three hormones is maintained at the level of the whole pancreas. It should be noted that the glucagon concentration of the remnant, equivalent was significantly lower than that of the whole pancreas.

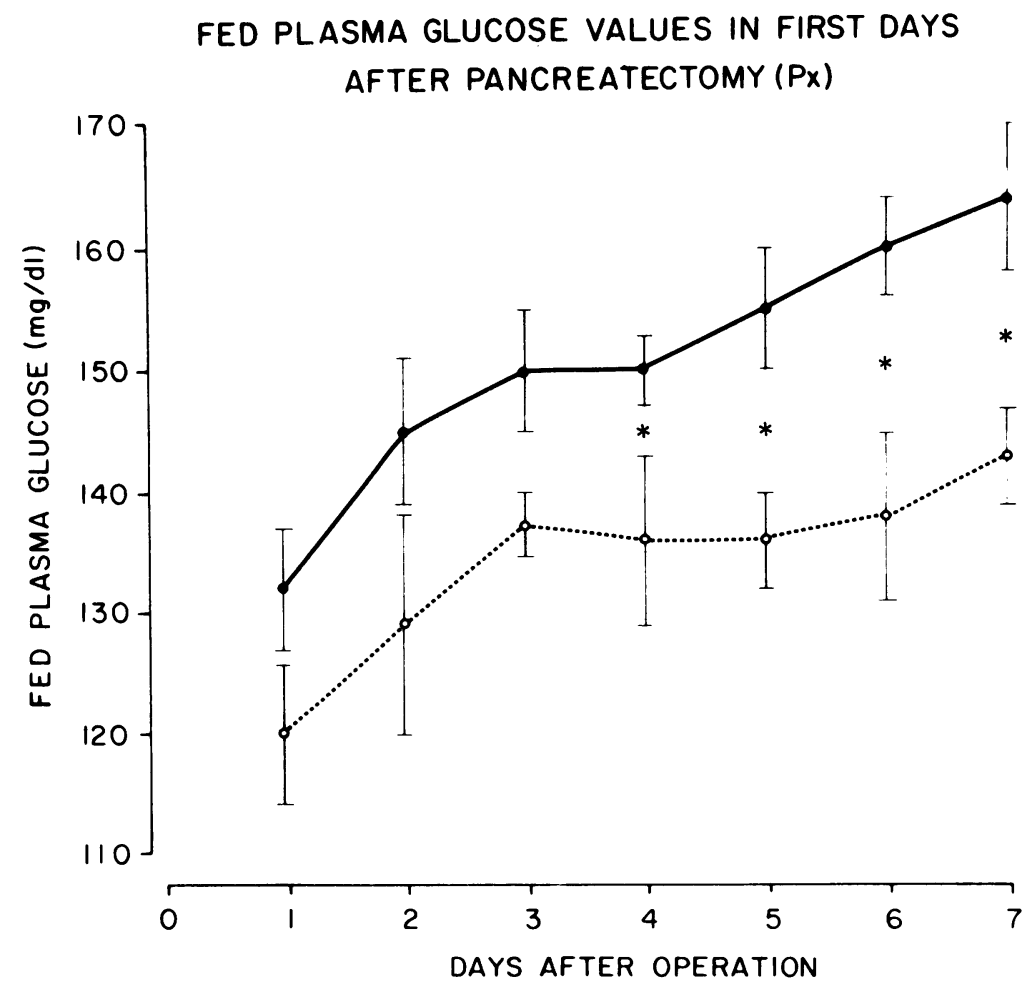

Figure 1 Effect of $\mathbf{9 0 \%}$ partial pancreatectomy $(\mathrm{Px})$ on the fed plasma glucose concentration during the first week following surgery. $\operatorname{Px}(-), n=14$; sham $(-\cdots), n=8{ }^{\bullet} 2 P \leq 0.05$. 


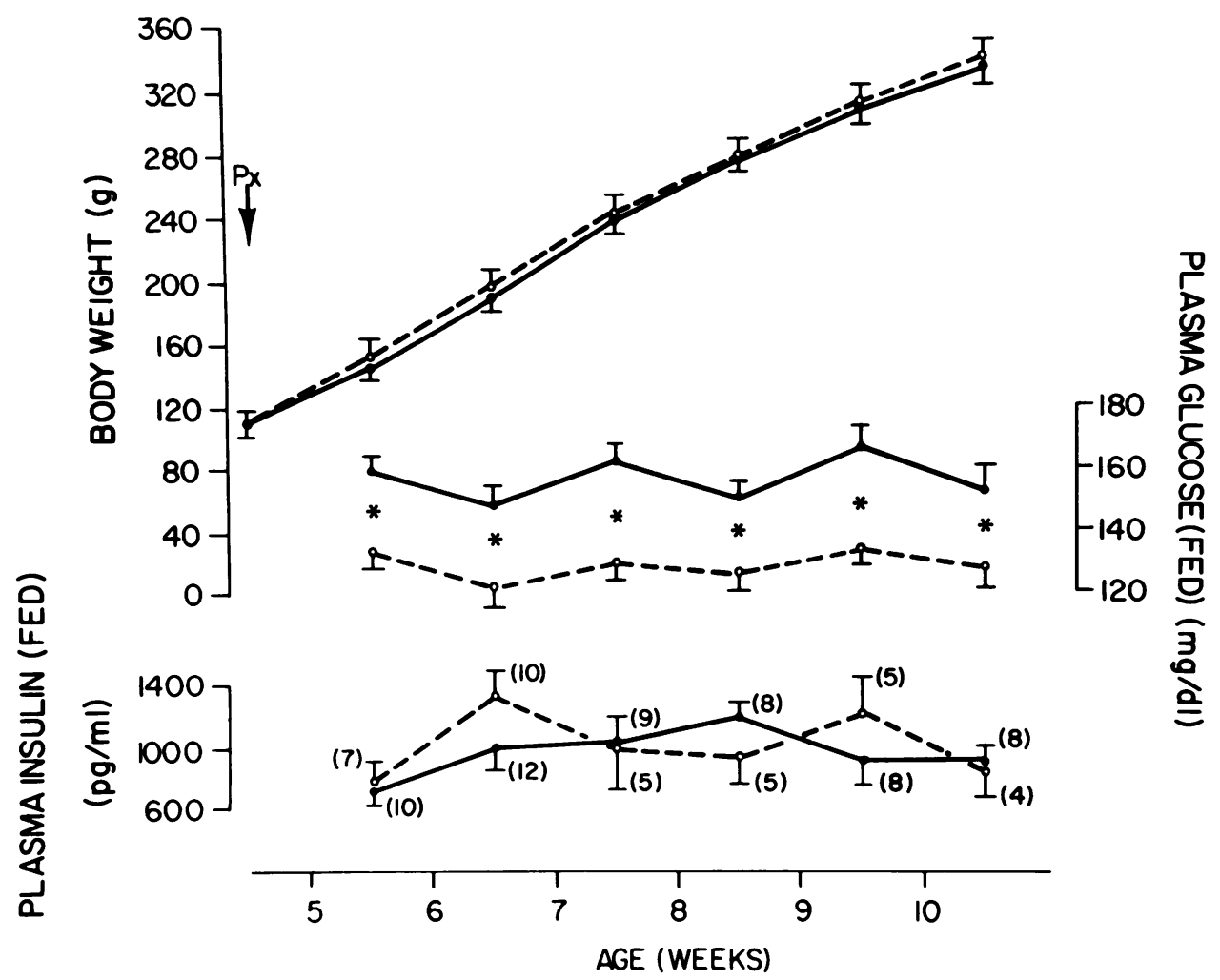

Figure 2 Effect of $90 \%$ partial pancreatectomy on the body weight (top graph) the fed plasma glucose concentration (middle graph) and the fed plasma insulin concentration (bottom graph). $\mathrm{Px}(-0), n=22$; $\operatorname{sham}\left(\mathrm{O}_{-}-\mathrm{O}\right), n=12$. $^{\circ} 2 P \leq 0.05$.

Morphology and morphometrics. The islet tissue in the pancreatectomy remnant $10 \mathrm{wk}$ after surgery was more heterogenous than controls when examined on immunoperoxidase-stained sections. There was great variation among animals but there were four distinct configurations found in most animals (Fig. 3): (a) normal appearing islets, which are the predominate population; (b) grossly larger islets with a seemingly lowered ratio of non-B-to-B cells; $(c)$ small islets with extremely few non-B cells; and $(d)$ fibrotic islets that show a disorganization of the usual mantle-core configuration. The fibrosis was restricted to the islet and perinsular region; there was no fibrosis between the exocrine acini.

Morphometric quantification dispelled the subjective impression that there was a change in the nonB-to-B cell ratio. The relative volumes (Table II) showed the same non-B-to-B cell ratio (remnant: $0.787 \pm 0.102 \%$ B cell $/ 0.195 \pm .030 \%$ non-B cell $=4.04$, $n=7$ vs. remnant equivalent: $0.462 \pm 0.038 \%$ B cells/ $0.103 \pm 0.014 \%$ non-B cells $=4.07, n=4$ ). However, when the mass of $B$ and non-B cells was calculated (with the assumption that the volume is equivalent to mass, i.e., $1 \mathrm{ml}=1 \mathrm{~g}$ tissue), it was clear that there had been considerable proliferation of $B$ and non-B cells after the partial pancreatectomy. The mass of both the B and the non-B cells were fourfold greater than those of the remnant equivalent of the same aged animal. To look at this another way, making the assumption that the remnant equivalent is truly representative of the whole pancreas, then the mass of $B$ and non-B cells in the whole pancreas can be calculated (Table II). The comparison of these values with those of the pancreatectomy remnant, showed that 8$10 \mathrm{wk}$ after partial pancreatectomy the remnant had $42 \%$ of the total B cell mass and $47 \%$ of the total non$B$ cell mass. Thus, the reduction of islet tissue did not remain at the $90 \%$ level of the pancreatectomy. Further calculations from these data give values for insulin content per milligram B cell tissue (Table II); there was no significant difference in this concentration even though there was a tendency for the remnant values to be decreased.

In vivo challenges. Animals studied 6-7 wk after partial pancreatectomy had normal fasting glucose and insulin values but were hyperglycemic after either a 

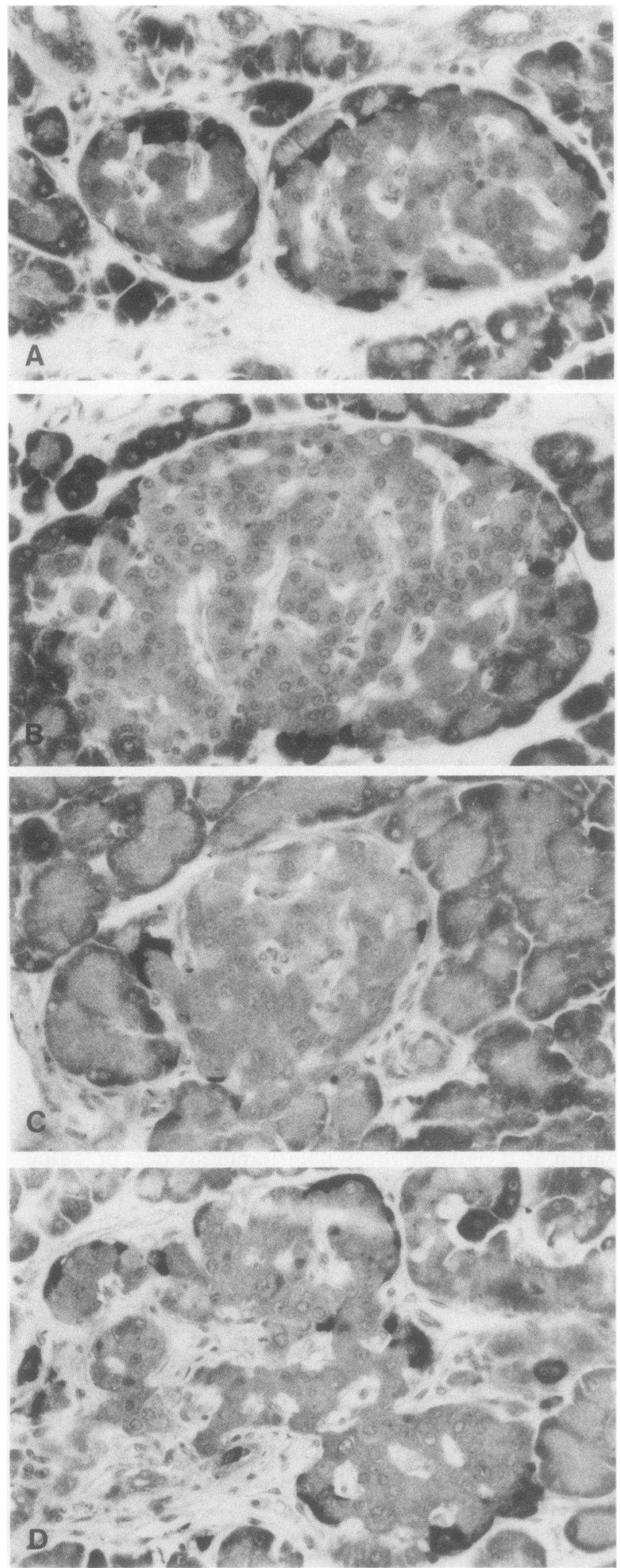

meal challenge or an IPGTT (Table 3 ). $30 \mathrm{~min}$ after the meal, the plasma insulin concentrations increased to a comparable degree in both the pancreatectomized and the sham-pancreatectomized (control) animals. However, in response to intraperitoneal administered glucose, the pancreatectomized animals did not show an increase in plasma insulin values whereas the controls did (Table III).

The data for the IVGTT and the IV ARG challenge, as presented in Table IV, show that the pancreatectomized animals have a dulled insulin response to glucose and a relatively better response to arginine. The difference in the insulin responses to these intravenous challenges is emphasized by comparing the increase above base line at $2 \mathrm{~min}$ in both groups. Taking into consideration the finding that the $B$ cell mass of the remnant in $42 \%$ of the sham control whole pancreas (Table II, which contains data from a comparable group of animals), it is apparent that the arginine responses are comparable in the two groups of rats, but that the responses to glucose are very different.

In vitro challenge with pancreatic perfusion. When the whole pancreases from the sham control rats were challenged with glucose $(300 \mathrm{mg} / \mathrm{dl})$, the expected biphasic response occurred; a clear response to arginine $(10 \mathrm{mM})$ was seen as well (Fig. 4 , Table V). In contrast, the pancreatic remnants from the rats that had received a partial pancreatectomy had a markedly impaired response to the high glucose challenge, but retained their ability to respond to arginine. As an additional control, the same challenges were given to seven pancreases in which perfusate flow was restricted to the remnant area. The responses, when expressed as percent rise from base line, were comparable to the results found with the whole pancreas. Thus the mean percent increase in response to high glucose for the whole pancreas was $612 \pm 101 \%$, for the restricted remnant area was $386 \pm 57 \%$, (not significant as compared to whole pancreas) and for the actual remnant was $159 \pm 21 \%(2 P \leq 0.001$ as compared with whole pancreas). The responses to arginine were for the whole pancreas $1,316 \pm 355 \%$, for the restricted remnant $1,259 \pm 215 \%$, and for the actual remnant $1,462 \pm 482 \%$.

It was of interest to compare the insulin responses of the remnant and sham-pancreatectomized whole

FIGURE 3 Photomicrographs of islets, stained for non-B cells (dark staining) by the peroxidase antiperoxidase method, showing the variety of islet configurations seen 8-11 wk after partial pancreatectomy $(\times 250)$. (A) Normal appearing islets that predominate. (B) Larger islets with seemingly reduced number of non-B cells. (C) Small islets with few non-B cells. (D) Large fibrotic islets in which the islet organization is disrupted. 
TABLE II

$B$ Cell and Non-B Cell Volumes and Insulin Concentration (as Function of B Cell Mass) in Remnant from Partially Pancreatectomized (Px) Rats, and in Remnant Equivalent and in Whole Pancreas from Sham-pancreatectomized (Sham Px) Rats

\begin{tabular}{|c|c|c|c|c|c|}
\hline \multirow[b]{2}{*}{ Animal $(n)$} & \multicolumn{2}{|c|}{ Relative volume ${ }^{\bullet}$} & \multicolumn{2}{|c|}{ Masst } & \multirow{2}{*}{$\begin{array}{c}\text { Insulin content } \\
\text { per unit of } B \text { cell mass }\end{array}$} \\
\hline & B cell & Non-B cell & B cell & Non-B cell & \\
\hline & \multicolumn{2}{|c|}{$\%$} & \multicolumn{2}{|c|}{$m g$} & $\mu g / m g$ \\
\hline Px remnant (7) & $0.787 \pm 0.102$ & $0.195 \pm 0.030$ & $2.33 \pm 0.25$ & $0.577 \pm 0.062$ & $8.90 \pm 1.12$ \\
\hline \multicolumn{6}{|l|}{ Sham Px (4) } \\
\hline Remnant equivalent & $0.462 \pm 0.038$ & $0.103 \pm 0.014$ & $0.576 \pm 0.555$ & $0.128 \pm 0.012$ & $11.1 \pm 2.3$ \\
\hline Whole pancreas $\S$ & - & 一 & $5.50 \pm 0.32$ & $1.23 \pm 0.07$ & $11.6 \pm 2.1$ \\
\hline
\end{tabular}

- Using the Weibel (12) point counting method on immunoperoxidase-stained sections, the relative volume was determined by dividing the number of intercepts over specifically stained cells by the number of total intercepts over pancreatic tissue.

I With the assumption that volume is the equivalent of the mass of a tissue, i.e., $1 \mathrm{ml}=1 \mathrm{~g}$ tissue, the mass is determined by multiplying the relative volume by the mean pancreatic weight as given in Table $I$.

$\$$ With the assumption that the remnant equivalent is representative of the whole pancreas, one can make calculations for the whole pancreas for comparisons.

pancreas in terms of either B cell mass or insulin content (Table $\mathrm{V}$ ). In both cases the insulin release elicited by $120 \mathrm{mg} / \mathrm{dl}$ glucose or $10 \mathrm{mM}$ arginine was comparable, but the response by the remnant to $300 \mathrm{mg} /$ dl glucose was clearly reduced. The secretion data for the whole pancreas experiments were used for these calculations instead of those from the acutely restricted remnants, because the latter were presumed to have more variability from acute surgical trauma.

\section{DISCUSSION}

Partial pancreatectomy resulted in discernible regeneration of the remnant and additionally in defective glucose-induced insulin release, which was shown by both in vivo and in vitro techniques. These findings add further weight to the hypothesis that excessive glucose stimulation of a reduced B cell mass leads to functional abnormalities of the B cell. Since similar

TABLE III

Meal Challenge and IPGTT ${ }^{\circ}$

\begin{tabular}{|c|c|c|c|c|c|c|c|}
\hline \multirow[b]{2}{*}{ Time (min) } & \multicolumn{3}{|c|}{ Meal challenge } & \multicolumn{4}{|c|}{ IPGTT } \\
\hline & 0 & 30 & 60 & 0 & 10 & 30 & 50 \\
\hline \multicolumn{8}{|l|}{ Pancreatectomy } \\
\hline $\begin{array}{l}\text { Plasma glucose }(m g / d l) \\
(n)\end{array}$ & $\begin{array}{r}96 \pm 5 \\
(14)\end{array}$ & $\begin{array}{l}184 \pm 6 \ddagger \\
\quad(14)\end{array}$ & $\begin{array}{l}181 \pm 7 \downarrow \\
(14)\end{array}$ & $\begin{array}{r}88 \pm 4 \\
(17)\end{array}$ & $\begin{array}{r}295 \pm 24 \\
(17)\end{array}$ & $\begin{array}{l}402 \pm 18 \ddagger \\
\quad(17)\end{array}$ & $\begin{array}{l}359 \pm 14 \ddagger \\
\quad(17)\end{array}$ \\
\hline $\begin{array}{l}\text { Plasma insulin }(n g / m l) \\
(n)\end{array}$ & $\begin{array}{c}0.34 \pm 0.03 \\
(7)\end{array}$ & $\begin{array}{l}1.0 \pm 0.12 \\
(14)\end{array}$ & - & $\begin{array}{c}0.43 \pm 0.08 \\
(9)\end{array}$ & $\begin{array}{c}0.49 \pm 0.04 ! \\
(10)\end{array}$ & $\begin{array}{c}0.52 \pm 0.06 t \\
(13)\end{array}$ & - \\
\hline \multicolumn{8}{|l|}{ Sham pancreatectomy } \\
\hline $\begin{array}{l}\text { Plasma glucose }(m g / d l) \\
(n)\end{array}$ & $\begin{array}{r}87 \pm 4 \\
(6)\end{array}$ & $\begin{array}{r}136 \pm 9 \\
(6)\end{array}$ & $\begin{array}{r}137 \pm 5 \\
(6)\end{array}$ & $\begin{array}{r}91 \pm 2 \\
(8)\end{array}$ & $\begin{array}{r}250 \pm 24 \\
(8)\end{array}$ & $\begin{array}{r}239 \pm 26 \\
(8)\end{array}$ & $\begin{array}{r}169 \pm 15 \\
(8)\end{array}$ \\
\hline $\begin{array}{l}\text { Plasma insulin }(n g / m l) \\
(n)\end{array}$ & $\begin{array}{c}0.58 \pm 0.16 \\
(4)\end{array}$ & $\begin{array}{c}1.42 \pm 0.34 \\
(6)\end{array}$ & - & $\begin{array}{c}0.41 \pm 0.09 \\
(5)\end{array}$ & $\begin{array}{c}1.93 \pm 0.38 \\
(4)\end{array}$ & $\begin{array}{c}1.89 \pm 0.25 \\
(4)\end{array}$ & - \\
\hline
\end{tabular}

- Animals were fasted $(19 \mathrm{~h})$ and given the meal challenge that consisted of receiving standard laboratory chow. $6 \mathrm{~d}$ later the same animals were fasted $(19 \mathrm{~h})$ and given an IPGTT $(2 \mathrm{~g} / \mathrm{kg}$ glucose).

$\downarrow 2 P \leq 0.001$, as compared with sham pancreatectomy. 
TABLE IV

IVGTT and IVARG Challenge ${ }^{\bullet}$

\begin{tabular}{|c|c|c|c|c|c|c|c|c|c|}
\hline \multirow[b]{2}{*}{ Time (min) } & \multicolumn{5}{|c|}{ IVGTT } & \multicolumn{4}{|c|}{ IV ARG challenge } \\
\hline & 0 & 2 & 5 & 10 & 30 & 0 & 2 & 5 & 15 \\
\hline \multicolumn{10}{|l|}{ Pancreatectomy } \\
\hline $\begin{array}{l}\text { Plasma glucose }(m g / d l) \\
(n)\end{array}$ & $\begin{array}{c}171 \pm 48 \\
(10)\end{array}$ & $\begin{array}{c}485 \pm 20 \\
(10)\end{array}$ & $\begin{array}{l}403 \pm 20 \downarrow \\
\quad(10)\end{array}$ & $\begin{array}{l}315 \pm 14 \S \\
\quad(10)\end{array}$ & $\begin{array}{l}211 \pm 15 \S \\
\quad(10)\end{array}$ & $\begin{array}{c}152 \pm 8 \rrbracket \\
(9)\end{array}$ & $\begin{array}{r}140 \pm 8 \\
(9)\end{array}$ & $\begin{array}{l}138 \pm 5 \\
(9)\end{array}$ & $\begin{array}{c}118 \pm 11 \\
(8)\end{array}$ \\
\hline $\begin{array}{l}\text { Plasma insulin }(n g / m l) \\
(n)\end{array}$ & $\begin{array}{l}1.6 \pm 0.3 \\
(10)\end{array}$ & $\begin{array}{l}2.7 \pm 0.4 \S \\
(10)\end{array}$ & $\begin{array}{c}2.5 \pm 0.4 \S \\
(9)\end{array}$ & $\begin{array}{l}2.0 \pm 0.3 \ddagger \\
(10)\end{array}$ & $\begin{array}{c}1.4 \pm 0.2 \\
(9)\end{array}$ & $\begin{array}{c}1.5 \pm 0.2 \\
(9)\end{array}$ & $\begin{array}{l}3.7 \pm 0.6 \ddagger \\
(9)\end{array}$ & $\begin{array}{c}2.3 \pm 0.3 \\
(9)\end{array}$ & $\begin{array}{c}1.3 \pm 0.3 \\
(8)\end{array}$ \\
\hline \multicolumn{10}{|l|}{ Sham pancreatectomy } \\
\hline $\begin{array}{l}\text { Plasma glucose }(m g / d l) \\
(n)\end{array}$ & $\begin{array}{r}120 \pm 7 \\
(10)\end{array}$ & $\begin{array}{c}422 \pm 23 \\
(10)\end{array}$ & $\begin{array}{c}330 \pm 25 \\
(10)\end{array}$ & $\begin{array}{c}237 \pm 11 \\
(10)\end{array}$ & $\begin{array}{r}112 \pm 7 \\
(10)\end{array}$ & $\begin{array}{l}129 \pm 6 \\
(9)\end{array}$ & $\begin{array}{r}119 \pm 8 \\
(9)\end{array}$ & $\begin{array}{l}125 \pm 6 \\
(7)\end{array}$ & $\begin{array}{c}106 \pm 12 \\
(7)\end{array}$ \\
\hline $\begin{array}{l}\text { Plasma insulin }(m g / d l) \\
(n)\end{array}$ & $\begin{array}{l}2.0 \pm 0.4 \\
(10)\end{array}$ & $\begin{array}{c}11.7 \pm 0.2 \\
(8)\end{array}$ & $\begin{array}{c}7.4 \pm 1.1 \\
(9)\end{array}$ & $\begin{array}{c}4.7 \pm 0.9 \\
(9)\end{array}$ & $\begin{array}{c}1.3 \pm 0.2 \\
(9)\end{array}$ & $\begin{array}{c}1.9 \pm 0.3 \\
(9)\end{array}$ & $\begin{array}{c}8.0 \pm 1.9 \\
(7)\end{array}$ & $\begin{array}{c}3.6 \pm 0.7 \\
(7)\end{array}$ & $\begin{array}{c}0.9 \pm 0.1 \\
(6)\end{array}$ \\
\hline
\end{tabular}

- 2-3 d before intravenous challenges, indwelling jugular catheters were put in place. Glucose $(60 \%$ solution, $1 \mathrm{~g} / \mathrm{kg})$ was injected in the cannula of animals in the fed state and then flushed with heparinized saline for the IVGTT. $4 \mathrm{~d}$ later the same animals again in the fed state received arginine hydrochloride solution $(180 \mathrm{mg} / \mathrm{ml}, \mathrm{pH} 7.4,300 \mathrm{mg} / \mathrm{kg}$ dose $)$ also via the cannula.

$\downarrow 2 P \leq 0.05$, as compared with sham pancreatectomy.

$\S 2 P \leq 0.005$, as compared with sham pancreatectomy.

secretory patterns were seen in both the neonatal streptozotocin model $(4,5)$ and these partial pancreatectomy findings, the possibility that streptozotocin caused this acquired defect seems less likely. In the neonatal streptozotocin model the reduction in B cell insulin content could lead to the suggestion that a defect in insulin production or storage led to the secretory defect. However, in the partial pancreatectomies, the B cell insulin content of the remnant was normal. The reason for these differences in insulin content of the two models is unknown, but perhaps the higher plasma glucose levels of the streptozotocin model led to degranulation. This is consistent with the demonstration that islets cultured at high glucose concentrations have depleted insulin stores and reduced insulin responses to acute glucose challenges $(20,21)$.

Even though the pancreatectomized rats had a clear defect in glucose-induced insulin secretion they were only moderately hyperglycemic. In the fed state plasma insulin concentrations were indistinguishable from control values, but taking into account the hyperglycemia, it can be argued that there is relative hypoinsulinemia. Nonetheless, the fact that the fed insulin levels are as well maintained as they are can probably be attributed to such nonglucose B cell stimuli as amino acids and gut hormones. Indeed, the in vitro and in vivo insulin responses of the remnant to arginine are essentially normal when expressed as a function of $B$ cell mass.
The partial pancreatectomy model (6-10) was a popular one several decades ago and the data from this work led to the often quoted concept that only $10 \%$ of the B cell mass is required to maintain a nondiabetic state. This is misleading for several reasons. First, there is regeneration of $B$ cell tissue such that the remnant in the present study contained $42 \%$ of the normal mass of B cells. Second, even though the fed plasma glucose levels of $\sim 160 \mathrm{mg} / \mathrm{dl}$ may seem unimpressive they are clearly higher than normal and unequivocal glucose intolerance is seen after either a glucose or meal challenge. Third, the partial pancreatectomy removes a substantial mass of glucagon-containing A cells, and this lack would be expected to further ameliorate the hyperglycemia. In a study by Martin and Lacy (10) $90 \%$ partial pancreatectomies on rats were also performed and $50 \%$ of the animals were clearly hyperglycemic $40 \mathrm{~d}$ following surgery. We cannot explain the increased severity of diabetes in their study, but differences in surgical technique or in the strain of the rats could be responsible for the discrepancy.

The regeneration of the remnant is of interest in that there were almost parallel increases in the mass of exocrine tissue, B cells and non-B cells. This was reflected by the concentrations of insulin, glucagon, and somatostatin in the remnant, equivalent to those found in whole control pancreas. The glucagon concentration of the remnant equivalent was lower than 


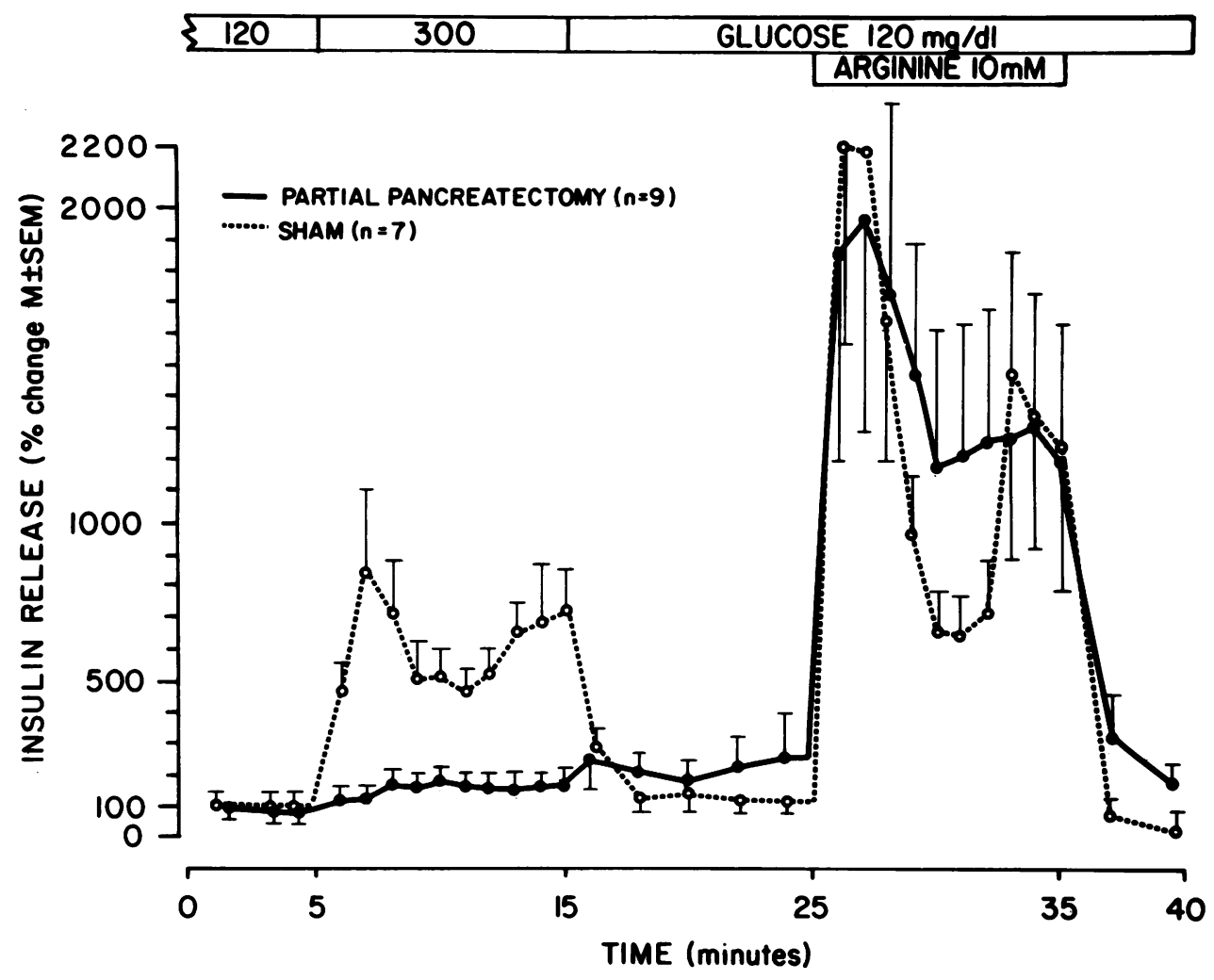

FIGURE 4 Insulin secretion in response to glucose and arginine from the perfused pancreatic remnant 8-11 wk after partial pancreatectomy. Control rats (sham) were sham pancreatectomized 8-11 wk earlier. All animals were studied in the fed state. The data are expressed as percent change from base line, rather than as the absolute quantity of insulin released, to make the two groups easier to compare.

that of either the remnant or the whole pancreas, and the reason for this difference is unclear. Certainly glucose stimulation to B cell growth (22) remains an at- tractive explanation for the increase of $B$ cell mass, but the manner in which this might be related to the growth of the other elements remains unknown. The

TABLE V

In Vitro Insulin Responses from Perfused Pancreatic Remnants (Px) and Sham-pancreatectomized Whole Pancreases (Sham Px) ${ }^{\bullet}$

\begin{tabular}{|c|c|c|c|c|c|c|}
\hline \multirow[b]{2}{*}{ Perfusate condition } & \multicolumn{2}{|c|}{ Insulin output! } & \multicolumn{2}{|c|}{ Insulin output/B cell mass } & \multicolumn{2}{|c|}{ Insulin output/insulin content\$ } \\
\hline & Sham Px & $\mathbf{P x}$ & Sham Px & $\mathbf{P x}$ & Sham Px & $\mathbf{P x}$ \\
\hline & \multicolumn{2}{|c|}{$n g / m i n$} & \multicolumn{2}{|c|}{$n g / m i n / m g$} & \multicolumn{2}{|c|}{ \% of content over $10 \mathrm{~min}$} \\
\hline Glucose, $120 \mathrm{mg} / \mathrm{dl}$ & $6.64 \pm 2.28$ & $2.27 \pm 0.76$ & $1.21 \pm 0.41$ & $0.98 \pm 0.33$ & $0.10 \pm 0.03$ & $0.11 \pm 0.04$ \\
\hline Glucose, $300 \mathrm{mg} / \mathrm{dl}$ & $32.2 \pm 8.4$ & $3.78 \pm 1.36^{\prime \prime}$ & $5.86 \pm 1.53$ & $1.62 \pm 0.58^{\prime \prime}$ & $0.50 \pm 0.13$ & $0.18 \pm 0.07^{\prime \prime}$ \\
\hline Arginine, $10 \mathrm{mM}$ & $52.1 \pm 8.8$ & $16.5 \pm 2.87^{\prime \prime}$ & $9.48 \pm 1.61$ & $7.09 \pm 1.23$ & $0.81 \pm 0.14$ & $0.80 \pm 0.14$ \\
\hline
\end{tabular}

- The number of perfusions for Px was nine and for Sham Px was seven.

$\$$ This refers to the mean output calculated from the initial 5-min period for $120 \mathrm{mg} / \mathrm{dl}$ glucose and the 10 -min periods for $300 \mathrm{mg} /$ dl glucose and $10 \mathrm{mM}$ arginine.

$\$$ The output for $120 \mathrm{mg} / \mathrm{dl}$ although measured for only $5 \mathrm{~min}$ was calculated as if for $10 \mathrm{~min}$ to allow comparisons with the two other conditions.

"Differs from Sham Px, $2 P \leq 0.02$. 
heterogeneity of islet configurations suggests that there may be replication of existing B cells in islets, but also possible neogenesis of complete islets. The pathogenesis of the fibrosis seen in some islets remains a puzzle, but we find no evidence indicating that it can be correlated with the degree of glucose intolerance as has been suggested by Clark et al. (23). Earlier studies have suggested that partial pancreatectomy accompanied by injections of anterior pituitary extract can lead to islet damage and "exhaustion" (7). Even though anterior pituitary extract was not used in this study, we found no evidence of islet destruction, and it does not yet seem reasonable to view the fibrosis in those terms. If the term exhaustion is used in a carefully defined restricted sense, one could, however, argue that there is a selective exhaustion of glucose-induced insulin secretion.

The results of the present study could have implications for our understanding of some of the abnormalities which are seen in NIDDM in man. The available morphological evidence suggests that $B$ cell mass in NIDDM is reduced to $\sim 60 \%$ of normal $(24,25)$. One can therefore speculate that this $B$ cell mass is stressed by hyperglycemia in the same manner as occurs in the partial pancreatectomy model, and that this leads to the selective defect in glucose-induced insulin release seen in NIDDM (26). Further support for this hypothesis comes from several studies which show that control of plasma glucose levels in NIDDM results in improved insulin secretion (27-29). There is emerging evidence for an abnormal structure of the 5 '-flanking region of the insulin gene in NIDDM $(30,31)$ and the relationship of this to the reduced $B$ cell mass and the abnormalities of insulin secretion in this disease remains to be unraveled.

\section{ACKNOWLEDGMENTS}

The authors thank D. Deal, E. Clore, and Lora Kramer for excellent technical assistance, and J. Reynolds and M. Graham for preparation of the manuscript.

This work was supported by grant AM-20349 from the National Institutes of Health.

\section{REFERENCES}

1. Deckert, T., U. B. Lauridsen, S. N. Madsen, and P. Mogensen. 1972. Insulin response to glucose, tolbutamide, secretin, and isoprenaline in maturity-onset diabetes mellitus. Dan. Med. Bull. 19: 222-226.

2. Robertson, R. P., and D. Porte, Jr. 1973. The glucose receptor. A defective mechanism in diabetes mellitus distinct from the beta adrenergic receptor. J. Clin. Invest. 52: 870-876.

3. Palmer, J. P., J. W. Benson, R. M. Walter, and J. W. Ensinck. 1976. Arginine-stimulated acute phase of insulin and glucagon secretion in diabetic subjects. J. Clin. Invest. 58: 565-570.
4. Bonner-Weir, S., D. F. Trent, R. N. Honey, and G. C. Weir. 1981. Responses of neonatal rat islets to streptozotocin: limited B cell regeneration and hyperglycemia. Diabetes. 30: 64-69.

5. Weir, G. C., E. T. Clore, C. J. Zmachinski, and S. BonnerWeir. 1981. Islet secretion in a new experimental model for non-insulin-dependent diabetes. Diabetes. 30: 590595.

6. Allen, F. M. 1922. Experimental studies in diabetes. Series III. The pathology of diabetes 1. Hydropic degeneration of islands of Langerhans after partial pancreatectomy. J. Metab. Res. 1: 5-41.

7. Lukens, F. D. W., and F. C. Dohan. 1942. Pituitarydiabetes in the cat; recovery following insulin or dietary treatment. Endocrinology. 30: 175-202.

8. Foglia V. G. 1944. Caracteristicas de la Diabetes en la Rata. Rev. Soc. Argent. Biol. 20: 21-37.

9. Houssay, B. A., R. R. Rodriquez, and A. F. Cardeza. 1954. Prevention of experimental diabetes with adrenal steroids. Endocrinology. 54: 550-552.

10. Martin, J. M., and P. E. Lacy. 1963. The prediabetic period in partially pancreatectomized rats. Diabetes. 12: 238-242.

11. Sternberger, L. A. 1974. Immunocytochemistry. Prentice Hall, Inc., Englewood Cliffs, NJ.

12. Weibel, E. R. 1963. Principles and methods for the morphometric studies of the lung and other organs. Lab. Invest. 12: 131-155.

13. Shah, J. H., N. Wongsurawat, P. P. Aran, G. S. Motto, and E. N. Bowser. 1977. A method for studying acute insulin secretion and glucose tolerance in unanesthetized and unrestrained rats. Diabetes. 26: 1-6.

14. Shah, J., B. Stevens, and B. J. Sorensen. 1981. Dissociation of the effects of vincristine on stimulated insulin release and the pancreatic B-cell microtubular structures in the intact rat. Diabetes. 30: 539-544.

15. Weir, G. C., S. D. Knowlton, and D. B. Martin. 1974. Glucagon secretion from the perfused rat pancreas. $J$. Clin. Invest. 54: 1403-1412.

16. Albano, J. D. M., R. P. Ekins, G. Maritz, and R. C. Turner. 1972. A sensitive precise radioimmunoassay of serum insulin relying on charcoal separation of bound and free hormone moieties. Acta Endocrinol. (Copenh.) 70: 487-509.

17. Weir, G. C., P. C. Goltsos, E. P. Steinberg, and Y. C. Patel. 1976. High concentration of somatostatin immunoreactivity in chicken pancreas. Diabetologia. 12: 129132.

18. Patel, Y. C., and S. Reichlin. 1978. Somatostatin in hypothalamus, extra-hypothalamic brain, and peripheral tissues of the rat. Endocrinology. 102: 523-30.

19. Soeldner, J. S., and D. Slone. 1965. Critical variables in the radioimmunoassay of serum insulin using the double antibody technic. Diabetes. 14: 771-779.

20. Andersson, A., J. Westman, and C. Hellerstrom. 1974. Effects of glucose on the ultrastructure and insulin biosynthesis of isolated mouse pancreatic islets maintained in tissue culture. Diabetologia. 10: 743-753.

21. Andersson, A. 1974. Long-term effects of glucose on insulin release and glucose oxidation by mouse pancreatic islets maintained in tissue culture. Biochem. J. 104: 377382.

22. Chick, W. L. 1973. Beta cell replication in rat pancreatic monolayer culture: effects of glucose, tolbutamide, glucocorticoids, growth hormone, and glucagon. Diabetes. 22: 687-693. 
23. Clark, A., E. Brown, T. King, R. I. Vanhegan, and R. C. Turner. 1982. Islet changes induced by hyperglycemia in rats: effects of insulin or chlorpropamide therapy. Diabetes. 31: 319-325.

24. Westermark, P., and E. Wilander. 1978. The influence of amyloid deposits on the islet volume in maturity onset diabetes mellitus. Diabetologia. 15: 417-421.

25. Saito, K., N. Yaginuma, and T. Takahashi. 1979. Differential volumetry of $A, B$, and $D$ cells in the pancreatic islets of diabetic and nondiabetic subjects. Tohoku J. Exp. Med. 129: 273-283.

26. Weir, G. C. 1982. Non-insulin-dependent diabetes mellitus: interplay between B-cell inadequacy and insulin resistance. Am. J. Med. 73: 461-464.

27. Turner, R. C., S. T. McCarthy, R. R. Holman, and E. Harris. 1976. Beta-cell function improved by supplementing basal insulin secretion in mild diabetes. $\mathrm{Br}$. Med. J. 1: 1252-1254.
28. Vague, P., and J.-P. Moulin. 1982. The defective glucose sensitivity of the $B$ cell in non-insulin dependent diabetes. Improvement after twenty hours of normoglycemia. Metab. Clin. Exp. 31: 139-142.

29. Hidaka, H., M. Nagulesparan, I. Klimes, R. Clark, H. Sasaki, S. L. Aronoff, B. Vasquez, A. H. Rubenstein, and R. H. Unger. 1982. Improvement of insulin secretion but not insulin resistance after short-term control of plasma glucose in obese type II diabetes. J. Clin. Endocrinol. Metab. 54: 217-222.

30. Rotwein, P., R. Chyn, J. Chirgwin, B. Cordell, H. Goodman, and M. A. Permutt. 1981. Polymorphism in the $5^{\prime}$ flanking region of the human insulin gene and its possible relation to type 2 diabetes. Science (Wash. DC). 213: 1117-1120.

31. Owerbach, D., and J. Nerup. 1982. Restriction fragment length polymorphism of the insulin gene in diabetes mellitus. Diabetes. 31: 275-277. 